\title{
Mediation Effects of Firm Leverage From the Perspective of Malaysian Shariah Compliant Companies - A Partial Least Square Structural Equation Modelling Approach (PLS-SEM)
}

\author{
Nur Ainna Ramli ${ }^{1}$, Nurshamimitul Ezza Ramli ${ }^{1}$, Ainulashikin Marzuki ${ }^{1} \&$ Muhamad Azrin Nazri ${ }^{1}$ \\ ${ }^{1}$ Faculty of Economics and Muamalat, University Sains Islam Malaysia, Bandar Baru Nilai, Malaysia \\ Correspondence: Nur Ainna Ramli, Faculty of Economics and Muamalat, University Sains Islam Malaysia, 71800, \\ Bandar Baru Nilai, N.Sembilan, Malaysia.
}

Received: April 8, 2020

doi:10.5430/rwe.v11n3p67
Accepted: May 11, 2020

Online Published: June 16, 2020

URL: https://doi.org/10.5430/rwe.v11n3p67

\begin{abstract}
There is a subsequent work from the previous studies on the relationship between firm-specific attributes and firm leverage. Then, during the last decade, international studies started to extend this field by scrutinizing how the firm leverage influences firm performance. However, much of the discussion from previous studies have not systematically investigated the simultaneously of the cause-effect framework on the impact of firm-specific attributes on firm financial performance through firm leverage which acts as a mediator variable. In short, it is reasonable to examine the mediating effects in which whether firm leverage may mediate or indirectly influence the relationship between firm-specific attributes and firm financial performance, particularly, from the perspective of Malaysian Shariah Compliant companies. The main motivation for this research is to contribute to corporate finance literature and how firms tend to choose their financing structure from the perspective of the capital structure theories. We obtained data of 398 Malaysian Shariah compliant companies from the Bursa Malaysia stock exchange with a total number of samples of 7414 for the sample data period from 2000 to 2018 . We find that there are three relationships that categorize as competitive mediation which is the relationships between the asset tangibility (AT), growth opportunities (GRW), firm size (FS) and firm financial performance. While, non-debt tax shield (NDTS) is categorized as a complementary mediation. We use the PLS-SEM approach in SmartPLS software 3.0 M3 to develop a set of mediation model from the perspective of capital structure theory for the Malaysian Shariah compliant companies.
\end{abstract}

Keywords: firm leverage, mediation effects, Malaysian Shariah Compliant companies, PLS-SEM, Islamic finance

\section{Introduction}

In Malaysia, Shariah Advisory Council (SAC) of Securities Commission (SC) formulated a new revised Shariah screening methodology of two-tier quantitative assessment for activity-based screening benchmarks and the newlyformulated financial ratio benchmarks, while the qualitative assessment remains the same. The revised methodology is an effort to expand the Islamic capital market's (ICM) international reach which is in line with the SC objectives (Nor M. F., et al (2019). In Islam, the level of firm leverage is set following the Prophet Muhammad (PBUH)'s words that $33 \%$ or 'one-third is enough'. This is evidenced by the hadith narrated by Imam Muslim in his book, The Book of Wasaya (Khan, 1997). Literature relating to the Islamic capital structure is still very few and limited. Among the few is Ahmed (2007). Ahmed suggests that being Shariah-approved firms, leverage employed must be asset-backed and the level of firm leverage must not exceed its tangible assets. In addition to that, Obaidullah (2006) explains that the Trade-off Theory (TOT) is not relevant to the Shariah-approved firms due to the element of the interest tax shield. To minimize the cost of financing, he proposes that Shariah-approved firms to choose internal equity, debt, Mudarabah-based equity and Musharakah-based equity. The order of choice proposed is similar to that of the Pecking Order Theory (POT). Nevertheless, depending on the objectives of the firms together with the constraints facing the firms and the different size and status, the preference of the financing sources may differ (Ahmed, 2007).

Both the conventional and the Islamic perspective see leverage through a different lens. Conventionally, Davis (1995) described leverage as a highly complex contract entailing a promise to repay the principal with the interest incurred 
on a loan or advance. Similar to the time value of money concept, where interest is included either explicitly or impliedly in all deferred payment transactions (Lokken, 1986). This concept views money as having greater benefits if received today rather than later. In the leverage contract, the interest charged to the borrower in order to compensate for the risk to the lender. The lender has absolute power on the interest rate charged to the borrower and in any case of default in loan repayment, the lender will charge for a penalty and even charging extra interest. This is basically the mechanism of a conventional contract protecting only the interest of the lender and transferring the risks to the borrower. In contrast, from the Islamic perspective, leverage is indispensable. However, leverage should not be encouraged for non-essential and wasteful consumption and unproductive speculation (Ahmed, 2010). Moreover, the leverage must be asset-backed and must be created from the sale or lease of real assets that the firms have by means of Murabahah, Ijarah, Salam, Istisna' and Sukuk modes of financing. Therefore, it is worth to discuss the firm leverage from the Islamic perspective that can maximize the firm value. Leverage is allowing in Islam but needs to follow the requirement of the Shariah perspectives especially, from the Malaysia Shariah Advisory Council (SAC) of Securities Commission (SC) that formulated a new revised Shariah screening methodology. In addition, it is believed that too much reliance on debt triggers bankruptcy risk and thus will affect the firm value and, also even worst will affect the whole economic system. Since leverage has the capability to create a problem, certain benchmark or guideline is definitely needed. This is where the concept of mediation effects arises in order to see how and whether the firm leverage can be influenced by mediates the relationships of the firm-specific attributes and firm financial performance. Firm performance has emerged as an important source of information for firm survival and long term return for investors, stakeholders and economy as a whole.

It is now well understood that certain important factors such as firm-specific attributes can affect firm leverage (see Booth et al., 2001; Deesomsak et al., 2004; Rajan and Zingales, 1995; Titman and Wessels, 1988). These attributes are also referred to as capital structure determinants. During the last decade, international studies started to appear investigating the relationship between firm leverage and firm financial performance (see Berger and Bonaccorsi Di Patti, 2006; Margaritis and Psillaki, 2007, 2010). It is reasonable to expect that those capital structure determinants would also influence firm financial performance. The development of Islamic capital market (ICM) in Malaysia is remarkably increasing with the size of Malaysia's Islamic capital market (ICM) is expected to expand at the average rate of 10.6\% per annum over the ten years to 2020 and to reach RM 2.9 trillion by 2020 (Haron and Ibrahim, 2012). This scenario offers an interesting platform to study the firm performance of Shariah compliant firms. Despite the growth of the Islamic capital markets in Malaysia, research on firm performance, especially among shariah-compliant companies remains relatively limited.

To empirically investigate the issues, this paper examines the influence of a set of variables on firm financial performance with focuses on firm attributes via firm leverage. The theory of capital structure determinants can be formulated as a causal model (Chang et al., 2009; Titman and Wessels, 1988). We use the PLS-SEM approach which combines features from principal component analysis and multiple regressions. PLS-SEM is a statistical approach to model the non-directly observed variable that can be measured by a variation of single and multiple observable indicators or proxies. This approach can also overcome multi-collinearity that sometimes happens in traditional regression. Investigating the mediation effect of firm leverage will be the main focus of this study. The inclusion of the third variable (the so-called mediator variable) such as firm leverage might influence the relationship of the two variables; that is, the predictor $\mathrm{X}$ (firm-specific attributes) and the outcome variable $\mathrm{Y}$ (firm financial performance). The benefits of the mediation effect can raise questions for the relationship between $\mathrm{X}$ and $\mathrm{Y}$ : "is there any variance in Y explained by $\mathrm{X}$, and is this a direct or indirect effect?" If there is a significant mediation effect (indirect), then "how much of the variance accounted for (VAF) is explained by the indirect effect (via the mediator variable)?" For instance, if the size of the mediating effect is $50 \%$, it indicates that only half of the total effect of the specific attribute on firm financial performance is explained by the mediating effect. To the best of my knowledge, only Ramadhan et al. (2012) and Ramli $(2016,2018,2019)$ have investigated the mediating effect of firm leverage between capital structure determinants and firm financial performance. Ramdhan et al (2012) clarify that firm leverage has a mediating effect between capital structure determinants and firm financial performance in the UK market, but their study has not motivated to examine the set of data from the perspective of Shariah compliant companies. Also, they do not disclose how the coefficient of the attributes led to the causal effects (Note 1). This gap in the literature gives valuable opportunities for this capital structure study. Therefore, the main objective of the study is to examine the impact of firm-specific attributes on firm financial performance through firm leverage which acts as a mediator variable from the perspective of Shariah Complaint companies. To the best of my knowledge, lack of studies particularly in developing country (i.e., Malaysia) has examined the overall model of firm-specific attributes and firm financial performance simultaneously from the perspective of Shariah Complaint companies. 
In order to examine the simultaneous of mediation effects and considering the gaps in previous studies, this study has developed the following research objectives:

(i) To investigate the direct effect between firm-specific attributes and firm financial performance of the Malaysian Shariah compliant companies.

(ii) To examine the relationship between firm-specific attributes and firm leverage of the Malaysian Shariah compliant companies.

(iii) To investigate the relationship between the firm leverage and firm performance of the Malaysian Shariah compliant companies.

(iv) To examine the mediation effects of firm leverage between the relationship of firm-specific attributes and firm performance from the perspective of the Malaysian Shariah compliant companies.

The remainder of this paper is organized as follows. The next section discusses the literature hypotheses and the capital structure from the Islamic perspective. Then, the following section describes the method of research. Following that, the data analysis and empirical results analysis are discussed. The final section presents the conclusions of the study.

\section{Literature Review}

The modern capital structure theories came into existence after the seminal works of Modigliani and Miller (1958) of a well-known capital structure irrelevance theory of MM I and MM II. The MM theorem assumes that in a perfect capital market, the value of the firm is independence from any form of capital structure. The MM also assumes similar business risks among firms operating in a similar business environment and firms are also assumed to pay no tax with zero transaction cost. The argument has initiated debates among researchers where the firm value being independence from the capital structure may encourage $100 \%$ debt to maximize their shareholder profit. This may lead to higher bankruptcy risk should there be default in loan repayment. Researchers also argue that in reality, the economy is operating in an imperfect capital market and the value of firms is determined not only by looking at debt and equity but also the consideration of other factors too such as taxes, transaction costs, bankruptcy costs, agency conflicts, adverse selection, lack of separation between financing and operations, time-varying financial market opportunities, and investor clientele effect (Frank and Goyal, 2008). Arguments and counter-arguments raised from the MM theory have led to the development of other capital structure theories such as the trade-off theory (TOT), the pecking order theory (POT) and the agency theory. The original TOT was derived from the MM theorem of Modigliani and Miller (1958) and Modigliani and Miller (1963). The TOT is basically looking at the cost and benefit of debt. By opting for debt, firms can reap the tax shield advantage that comes with debt employment, where the higher the level of debt employed the bigger tax shield it will enjoy. The POT is basically hierarchical financing with internal financing being the first option of financing as compared to external financing. The POT is derived from the asymmetric information problem. The agency theory initiated by Jensen and Meckling (1976) is an extension to the earlier work of Fama and Miller (1972). Agency conflict may occur between the stockholders and the managers and between the stockholders and the debt holders.

\subsection{The Islamic Perspective on the Firm Leverage}

Interest $\left(r i b a^{\prime}\right)$ is strictly prohibited in Islam. Nevertheless, the concept of the time value of money is still relevant in Islamic finance (Bacha and Mirakhor, 2013). Time value of money is essential in evaluating cash flows, investment appraisals and financial decision-making - not only in conventional finance but in Islamic finance as well. In Islam, the opportunity cost is incurred only when the available option is an equally good choice (Suharto, 2014). If a person faces both a good choice and a bad choice, discarding the bad choice is not regarded as opportunity cost. Thus, the bad choice is not even considered a choice in Islam. The Islamic notion of the opportunity cost of capital and the time value of money can be clearly understood by reviewing the distinctions between investment and lending (Iqbal and Mirakhor, 2011). Money can be used both for investment purposes and to be lent to those in need. A party to an investment contract, such as in Mudarabah or Musharakah, will be compensated accordingly with the specific profit and loss agreed on in the contract. Money, in this case, acts as a medium of exchange to facilitate an economic activity over a certain time period. Islam does recognise return from this investment activities thus the investors have compensated accordingly. Even though the concept of the time value of money is permissible in the Islamic finance, it is not so in the context of debt (Obaidullah, 2005) due to riba' that results when a higher debt replaces a lower debt. Islam sees the act of lending money as a charitable act based on the qardul hassan, or charitable contract. Conventionally, interest on a loan is perceived as a reward to the lender (as at the same time the recipient's opportunity cost). Nevertheless, Islamic scholars see this as an unlawful act. Islam regards lending as solely a 
charitable act without expecting any monetary reward in return. Lending money without expecting anything in return is an act done for the sake of receiving Allah's blessing (barakah) and to uphold the spirit of helping each other (ta'awun).

\subsection{Firm-Specific Attributes}

\subsubsection{Asset Tangibility}

Asset tangibility is an important determinant of capital structure as it can explain why firms leverage changes substantially. It can also explain the issue of low leverage puzzle (Rampini and Viswanathan, 2013). Tangibility also recorded mixed relationship in the literature. The positive relationship between tangibility and leverage is following the TOT hypothesis. Firms with higher asset tangibility can engage with a higher debt level as tangible assets can act as collateral. Hall (2012) in his study on firms in the Central and Eastern Europe, reported a positive significant relationship between asset tangibility and the level of debt. Mustapha et al. (2011) and Baharuddin et al (2011), share the same result for firms in Malaysia. Hassan et al. (2012) in their comparative analysis between listed Shariah and non-Shariah-approved firms in Malaysia conclude that tangibility does have positive significant roles in influencing debt level for Shariah-approved firms but not the conventional. Further, Ramli and Haron (2017) concurred a positive relationship between debt and asset tangibility for Shariah approved firms in Malaysia using the GMM model for the period of analysis from 2000 to 2014. Nevertheless, Al-Najjar and Hussainey (2011) and Psillaki and Daskalakis (2008) record a negative relationship between tangibility and leverage.

\subsubsection{Growth Opportunities}

Growth is expected to have a positive relationship with leverage supporting the POT theory. As firms are growing, the investment level will increase thus larger funds are needed. Byoun (2011) explains that the tendency of the firms to utilize its financial flexibility to fund their future growth may also influence the impact of growth on leverage. In addition to that, financial flexibility does play a part as it allows firms to maintain a low level of debt. When the firms decide to expand they can use and rely on their financial stability to engage in more debt. The positive relationship between growth opportunity and level of debt is evidenced in Al-Najjar and Hussainey (2011) and Tongkong (2012). The TOT, on the other hand, hypothesises an inverse relationship between growth and leverage. As the firm grows, the costs of financial distress also increase. Bankruptcy cost will consequently increase thus the level of debt will be reduced. This is also consistent with Myers and Majluf (1984) and Deesomsak et al., (2004).

\subsubsection{Firm Size}

Previous studies on the relationship between the size of the firms and leverage recorded mix results. The positive relationship between size and leverage is consistent with the TOT. Large firms are usually more diversified with a more stable earning thus are keen to employ debt in their capital structure as to reap the tax shield that comes with debt employment. The positive relationship between firms' size and leverage can be seen in Psillaki and Daskalakis (2008) and Tongkong (2012). On the other hand, studies by Ting and Lean (2011) on the listed government-linked companies (GLCs) in Malaysia support the POT suggesting an inverse relationship between size and the level of leverage. This is perhaps large firms usually have low information asymmetry problem thus, can afford to opt for equity financing rather than debt financing. While, with regard to the Shariah-approved firms, Hassan et al. (2012) show evidence that size does affect the debt level of the firms positively. Firm's size also found as a robust indicator in determining Shariah firm's debt level in Malaysia using fixed-effect robust cluster model as concurred by Ramli and Haron (2017). However, Ahmad and Azhar (2015) are not able to provide evidence on any significant relationship between size and debt for the Shariah-approved firms in Malaysia from the consumer sector.

\subsubsection{Non Debt Tax Shield}

The TOT explains that firms employ debt financing to enjoy tax shield benefit (Modigliani and Miller, 1963). Nevertheless, a higher debt level means a higher cost of debt like bankruptcy risk and agency cost. This may offset the benefits from the tax shield. Deangelo and Masulis (1980) explain that NDTS such as depreciation deduction and investment tax credit provides alternatives to tax shield benefit that comes with debt. Firms may, therefore, utilize their NDTS as their tax saving strategy instead of opting for debt financing. Literature recorded a negative relationship between NDTS and leverage (González and González, 2012) following the TOT. Chakraborty (2010) on the other hand found a positive relationship between debt and NDTS and may possibly due to the tax shield advantages. With respect to the Shariah-approved stocks, Hassan et al. (2012) depicted a positive relationship between NDTS and debt level. 


\subsection{Indirect/Mediation Effects}

The terms indirect and mediator are interchangeable. In a situation where a variable $\mathrm{X}$ is hypothesized to exert an effect on criterion variable $\mathrm{Y}$ through a third variable (one or more intervening variables), the third variable is referred to as the mediator variable. We examine the impact of the firm specific attributes on firm financial performance as mediated by firm leverage. This assumes that a firm's financing structure influences the way in which the firm characteristics impact on firm financial performance. For example, with respect to asset tangibility, firms with more tangible assets have more collateral to support higher debt levels. This is consistent with the Agency Theory in that it can reduce the agency cost of debt which will in turn, generate more productivity in the value of the firm. This high level of tangible assets may also indicate a good reputation in getting funds, and thus is useful for a profitable project leading to more returns. Ramdhan et al (2012) clarify that firm leverage has a mediating effect between capital structure determinants and firm financial performance in the UK market. Ramli et al. (2019) examine firm leverage as a mediator variable between capitals structure determinants and firm financial performance in the Malaysia and Indonesia market. However, their studies only focus on the conventional counterpart and not highlight whether there is a mediating effects from the perspective of Shariah Compliant companies. Also, they do not disclose how the coefficient of the attributes led to the causal effects (Note 1). This gap in the literature gives valuable opportunities for this capital structure study, especially from the perspective of Malaysian Shariah compliant companies. Therefore, it is hypothesized that firm leverage has an indirect/mediation effect on firm-specific attributes and firm financial performance for Malaysian Shariah Compliant companies. Figure 1 shows that this study has total of 6 constructs (Latent Variables), namely, asset tangibility, growth opportunity, firm size, non-debt tax shield, firm leverage and firm financial performance. The diagram explains the simultaneous of mediation effects for research objectives of the study; (i) objective 1 is the path coefficient from the firm-specific attributes to firm financial performance, (ii) objective 2 is the path coefficient from the firm-specific attributes to firm leverage, (iii) objective 3 is the path coefficient from the firm leverage to firm financial performance, and objective 4 is the mediation effect of firm leverage between the relationship of firm-specific attributes and firm financial performance.

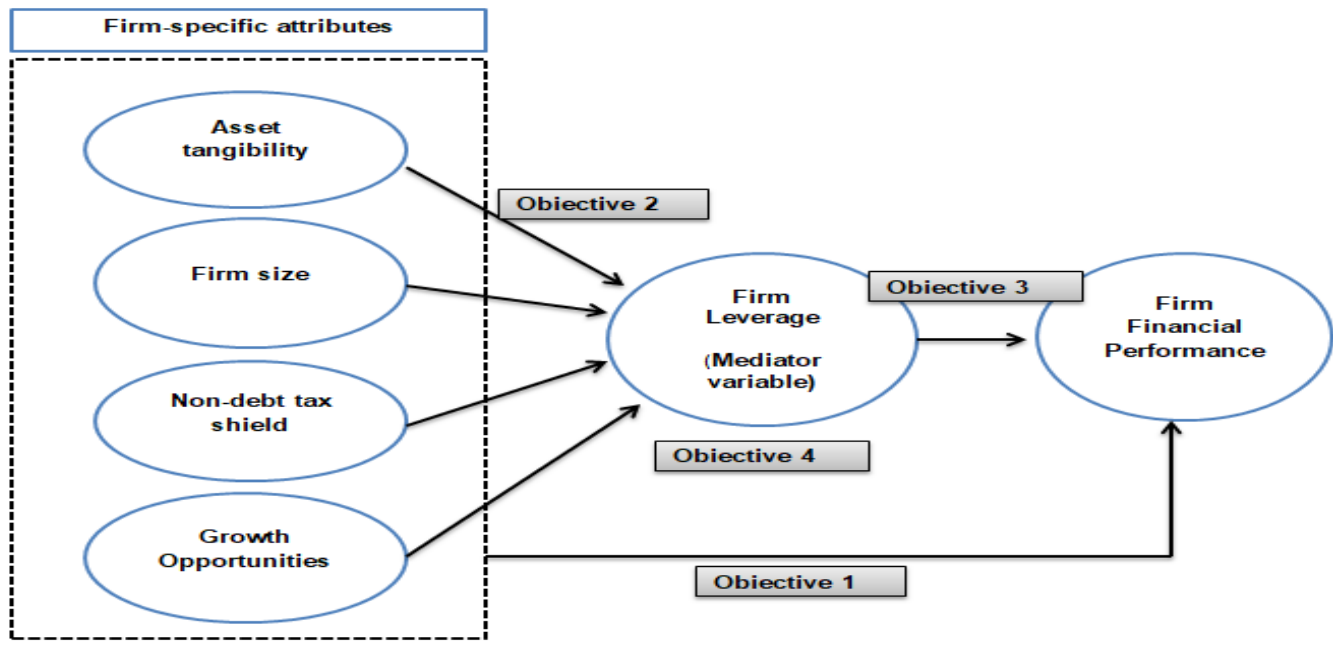

Figure 1. Construct of the mediation effects

\section{Methodology}

In this study, firm leverage (M) is the mediator variable for the relationship between firm-specific attributes (X) and firm financial performance $(\mathrm{Y})$.

$\mathrm{X}, \mathrm{M}$ and $\mathrm{Y}$ are referred to as latent variables that will be measured by manifest indicators,

$\mathrm{x}_{1} . . \mathrm{x}_{3}, \mathrm{~m}_{1} . . \mathrm{m}_{3}$ and $\mathrm{y}_{1} . . \mathrm{y}_{3}$, respectively.

The measurement equation can be expressed as: 
Let's say, $x_{i}=\lambda_{i 1} X_{1}+\varepsilon_{i 1}$

Where;

i) $\quad x_{i 1}$ is the vector of the $i^{\text {th }}$ manifest indicator of the vector of the latent variable of $\mathrm{X}_{i}$,

ii) $\quad \lambda_{i 1}$ is the matrix of factors loading for the $i^{\text {th }}$ manifest indicator of $x_{i 1}$ to the latent variable of $\mathrm{X}_{i}$ (a matrix of regression coefficient of $x_{i 1}$ on $\mathrm{X}_{\mathrm{i}}$ ) and;

iii) $\quad \varepsilon_{i 1}$ is a vector of the measurement error in the model.

The measurement model represents the measurement model for $\mathrm{X}$ firm-specific attributes (Asset tangibility, Firm Size, Growth Opportunities, Non-Debt Tax Shield). This equation can be represented according to the symbol for the manifest indicator, and the measurement error in the path diagram, e.g., the symbols for the indicator and measurement error for firm leverage (Total debt ratio) are $m$ and $\varepsilon$, and for firm financial performance (ROA, ROE and ROIC) are $y$ and $\varepsilon$.

The structural model equation is:

$$
\mathrm{Y}=\beta_{0}+\beta \mathrm{X}+\beta \mathrm{M}+\varepsilon
$$

Where;

i) $\quad \mathrm{Y}$ is the endogenous latent variable,

ii) $\quad \beta$ is the vector matrix of regression coefficient to the vector of exogenous latent variables $X$ and $M$, and;

iii) $\quad \varepsilon$ is the residual for the structural equation model (inner model). The standard error and the estimation parameter in the measurement and structural models are estimates using the bootstrap procedure.

\subsection{Data Sample and Measurement}

We obtained data of 398 Malaysian Shariah companies from the Bursa Malaysia stock exchange and the data of firm-specific attributes were gathered from the DataStream database. We use the PLS-SEM approach in SmartPLS software 3.0 M3. PLS-SEM for the sample data period is from 2000 to 2018 with the total number of samples of 7414. From the total sample, any data that were not complete records were excluded from the analysis.

The study has 6 constructs (LVs) namely, asset tangibility, growth opportunity, firm size, non-debt tax shield, firm leverage and firm financial performance. This study model specification for PLS-SEM includes the measurement model (e.g. formative and reflective construct) and structural model. The measurement model consists of one reflective constructs (e.g. Non-debt tax shield) and five formative constructs (e.g. asset tangibility, growth opportunity, firm size, firm leverage and firm financial performance). The firm-specific attributes and their indicators or proxies for the particular constructs are as follows: asset tangibility (AT) with its indicator of fixed assets to total assets; growth opportunity (GRW) with its indicators of Tobin Q ( market value of equity plus the book value of debt and divided with the total assets); firm size (FS) with its indicators size of log net sales and non-debt tax shield (NDTS) with its reflective indicators, namely operating income to total assets (NDTS-OI) and total annual depreciation to total assets (NDTS-DEP). The structural model is the path coefficient between the latent variable of the exogenous variable (i.e., firm-specific attributes) and the endogenous variable which consists of firm leverage and firm financial performance. The firm leverage has one formative indicator which is total debt ratio (TDR), while the firm financial performance has three formative indicators, namely the return on equity (ROE), return on assets (ROA) and return on invested capital (ROIC).

Some studies argue that book leverage is a better measure to identify a firm's asset value. This is because it can capture the firm's assets in place rather than discretionary investment growth that is likely reflected in the future (Barclay et al., 2006; Harris and Raviv, 1990). Future investment may be distorted by the use of market value in leverage decisions. However, some studies suggest that market leverage provides a more realistic measurement for leverage because it closely reflects the intrinsic value and potential for future leverage (Kayo and Kimura, 2011). The use of market leverage reflects a firm's financial sag and book leverage reflects the use of financing assets in place. Because of this controversy, we only use total debt ratio (TDR) as firm leverage that acts as a mediator variable. To achieve the research objectives and several steps have been conducted. The first step assesses the two 
constituents in PLS-SEM, the measurement and structural sub-models. The measurement sub-model is estimated to test construct convergent validity and construct reliability. This test is essential to obtain the reliability and consistency of the data statistics for each indicator/proxy with its construct. The second step assesses the structural model that explains the relationship between the exogenous and endogenous variables. This structural model was tested in PLS-SEM for its statistically significant value. In the final step the bootstrap t-statistics (Hair et al., 2013; Preacher and Hayes, 2008) were used to test whether leverage mediates the effect between the firm-specific attributes and firm financial performance.

\section{Measurement and Structural Model Results}

Table 1. Descriptive statistics for the exogenous and endogenous indicators

\begin{tabular}{lccccc}
\hline \multicolumn{1}{c}{ Variable } & Indicators & Min & Max & Mean & Std. Dev. \\
\hline Asset tangibility & AT & 0.00 & 0.97 & 0.352 & 0.22730 \\
Growth opportunities & TobinQ & 0.00 & 23.219 & 0.2142 & 0.43188 \\
Firm size & FS & 0.00 & 7.702 & 5.298 & 0.7643 \\
Non-debt tax shield & NDTS-OI & -2.884 & 11.106 & 0.0343 & 0.1661 \\
& NDTS-DEP & 0.00 & 0.288 & 0.023 & 0.0221 \\
Total Debt ratio & TDR & 0.00 & 23.217 & 0.213 & 0.4319 \\
Firm financial performance & ROE & -4812 & 1858 & 3.00 & 87.680 \\
& ROA & -137.32 & 771 & 3.79 & 14.842 \\
& ROIC & -274 & 288 & 4.66 & 14.318 \\
\hline
\end{tabular}

Table 2. The measurement model

Measurement results of the factorial construct validity for the endogenous and exogenous variables hypothesised to influence the firm-specific attributes and firm financial performance estimated using Partial Least Square which is variance based Structural Equation Modelling (PLS-SEM). The measurement estimates are calculated by the PLS algorithm with the path weighting scheme, Mean 0, Variance 1, Maximum iteration 300.

\begin{tabular}{lcc}
\hline Exogenous & AVE & CR \\
\cline { 2 - 3 } Asset tangibility & 1.000 & 1.000 \\
Growth Opportunities & 1.000 & 1.000 \\
Firm Size & 1.000 & 1.000 \\
Non debt tax shield & 0.500 & 0.509 \\
Endogenous & & \\
Firm Leverage & 1.000 & 1.000 \\
Firm Financial Performance & 1.000 & 1.000 \\
R-Squared(R2) & & \\
$\mathrm{R}^{2}$ - Leverage & & \\
$\mathrm{R}^{2}$ - Firm Financial Performance & & \\
\hline
\end{tabular}

Note: AVE is defined as average variance extracted, and CR is defined as composite reliability. This study model specification for PLS-SEM includes the measurement model (e.g. formative and reflective construct) and structural model. One reflective constructs (e.g. Non-debt tax shield) and five formative constructs (e.g. asset tangibility, growth opportunity, firm size, firm leverage and firm financial performance). The structural model is the path coefficient between the latent variable of the exogenous variable and the endogenous variable which consists of firm leverage and firm financial performance.

Table 1 shows the summary descriptive statistics of mean and standard deviations for exogenous and endogenous variables. Table 2 presents the results of the measurement models (convergent validity and construct reliability) for 
Malaysian Shariah Compliant companies. The measurement model assessments have met the commonly suggested criteria (see the example from Chin, 1998; Chin et al., 2010; Henseler et al., 2009). Specifically, the Average Variance Extracted (AVE) values are above 0.5 and the composite reliability (CR) value for most of the constructs achieves a higher value of at least 0.7. The Variance Inflation Factor (VIF) shows the measurement model assessments are robust (VIF $<10)$ and thus, indicating no problems with multi-collinearity. The $\mathrm{R}^{2}$ reflects the power of construct variances in determining the goodness of fit against the manifest items (Chin, 1998). All the $\mathrm{R}^{2}$ reported in Table 2 shows that firm leverage is above 0.9 which indicate that the model's explanatory power provide a better predictive ability for the dependent variable. However, for firm performance, the $\mathrm{R}^{2}$ reported as a weak predictive ability maybe due to the exclusion of some important factors that determines the firm performance variables (Note 2). The significant value and structural coefficient estimates among the latent variables (LVs) are presented in Table 3.

Table 3. Statistically significant value (the structural model) for Malaysian Shariah companies

\begin{tabular}{lcccc} 
Panel A & coef. $(\beta)$ & Std.error & T-stats & P-values \\
\cline { 2 - 5 } Asset tangibility -> firm leverage & -0.018 & 0.004 & 4.843 & $0.000^{* * *}$ \\
Growth opportunity -> firm leverage & 0.991 & 0.006 & 157.56 & $0.000^{* * *}$ \\
Firm size -> firm leverage & -0.030 & 0.007 & 4.396 & $0.000^{* * *}$ \\
Non-debt tax shield -> firm leverage & 0.011 & 0.003 & 3.986 & $0.000^{* * *}$ \\
Panel B & & & & \\
Asset tangibility -> firm financial performance & -0.045 & 0.017 & 2.616 & $0.009^{* * *}$ \\
Growth opportunity -> firm financial performance & -0.418 & 0.145 & 2.888 & $0.004^{* * *}$ \\
Firm size-> firm financial performance & 0.200 & 0.083 & 2.413 & $0.016^{* *}$ \\
Non-debt tax shield -> firm financial performance & 0.352 & 0.165 & 2.129 & $0.033^{* *}$ \\
Firm leverage -> firm financial performance & 0.304 & 0.133 & 2.280 & $0.023^{* *}$ \\
\hline
\end{tabular}

Note: $* * *, * * *$ means statistically significant at the 1 per cent, 5 per cent and 10 per cent levels, respectively. Formative indicators are asset tangibility (AT), growth opportunity (GRW), firm size (FS), total debt ratio (TDR) and Firm financial performance (FFP). The reflective indicator is a non-debt tax shield (NDTS).

Table 3 presents the PLS-SEM statistically significant estimates for the firm-specific attributes to firm leverage (Panel A) and a PLS-SEM statistically significant estimate for the firm-specific attributes to firm financial performance (Panel B). The PLS path model measures the Beta ( $\beta$ ) coefficient, standard error and statistically significant values using resampling from the bootstrapping procedures for 5000 samples for all samples. Based on the relationships between the firm specific attributes and firm leverage in Panel A, we find that the asset tangibility (AT) and firm size (FS) are statistically significant and negatively correlated with the firm leverage. The result of firm size to leverage is consistent with the Pecking Order Theory (POT) due to probably of the problem of information asymmetry is less severe in large firms compared with small firms and thus, large firms prefer to issue equity instead of debt (Rajan\& Zingales, 1995). The result of the negative relationship between asset tangibility and firm leverage is consistent with Rajan and Zingales (1995) and Grossman and Hart (1982). This is probably due to Malaysian Shariah firms tend to consume less debt to minimize the threat of bankruptcy. Based on the result for the relationships of growth opportunities (GRW) and non-debt tax shield (NDTS) to firm leverage, it shows a statistically significant and positive correlated. This is consistent with the POT that there is information asymmetry between managers and investors (Myers and Majluf, 1984). According to tax based theory, capital structure decisions are influenced by consideration of tax and bankruptcy costs. This shows that the debt financing for the Malaysian Shariah companies take an advantage of a substitute for a tax benefit (i.e., NDTS) which is an alternative method of reducing the tax burden (Deangelo and Masulis, 1980). Based on the results relationships between the firm specific attributes and firm financial performance in Panel B, we find that the asset tangibility (AT) and growth opportunities (GRW) are statistically significant and negatively correlated with the firm financial performance. While the firm size (FS) and non-debt tax shield (NDTS) are statistically significant and positively correlated with the firm financial performance. This shows that the sample of Malaysia Shariah companies has stable cash flow and are more diversified, which tends to let the firms better exploit the economies of scale. 


\subsection{Mediation Result}

Table 4. Mediation results

\begin{tabular}{lcc}
\hline Path mediating effects & t-statistics & Result \\
\hline Asset tangibility $->$ firm leverage $->$ firm financial performance & $2.655^{* * *}$ & Accepted \\
Growth opportunities $->$ firm leverage -> firm financial performance & $2.269^{* * *}$ & Accepted \\
Firm size -> firm leverage -> firm financial performance & $2.846^{* * *}$ & Accepted \\
Non-debt tax shield $->$ firm leverage $->$ firm financial performance & $2.212^{* * *}$ & Accepted \\
\hline
\end{tabular}

**,*Statistically significant at the 5 per cent and 10 per cent levels, respectively, using standard errors that have been generated from the 5000 random bootstrapping procedure samples (with replacement). The null hypothesis will be rejected if the $\mathrm{t}$-value exceeds 1.96 (at $\mathrm{p}<0.05$ ), i.e., there are no mediating/indirect effects of firm leverage between the relationship of firm-specific attributes and firm financial performance. Note: The mediation tests are measured as follows: The bootstrap t-statistic is measure by $t_{e m p}=w /\left[(s e(w)]\right.$ where: $t_{e m p}$ is the empirical t-value, $\mathrm{w}$ is the original PLS estimate of a certain path coefficient, and $\mathrm{se}(\mathrm{w})$ is the bootstrapping of the standard error. These significance test estimates are claimed to perfectly suit the PLS-SEM technique (Hair et al., 2017; Preacher \& Hayes, 2008).

A mediation model hypothesizes that the independent variable $(\mathrm{X})$ influences the mediator variable $(\mathrm{M})$ which, in turn, influences the dependent variable $(\mathrm{Y})$. We focus on the simultaneous relationship between firm-specific attributes $(\mathrm{X})$, firm leverage $(\mathrm{M})$ and firm financial performance $(\mathrm{Y})$. The advent of SEM with simultaneous analysis can extend the path analysis coefficients from path coefficient " $a$ " of the firm-specific attributes $(\mathrm{X})$ to firm leverage (M), path coefficient " $b$ " of firm leverage (M) to firm financial performance (Y) and path coefficient " $c$ " of the firm-specific attributes $(\mathrm{X})$ to firm financial performance $(\mathrm{Y})$. Table 4 presents the mediation results. The results show that the relationships between all the firm-specific attributes and firm financial performance have been mediated by the firm leverage for Malaysian Shariah compliant companies. The result is consistent with the previous studies (Ramli et al., 2016, 2019) that examine the mediation effects of leverage for the Malaysian sample. We report that there is an exist of mediation effects of leverage between the relationships of asset tangibility (AT), growth opportunities (GRW), firm size (FS) and non-debt tax shield (NDTS) and firm financial performance. The result shows that the path "b" which is the relationship between the firm leverage and firm financial performance is significant and positively correlated (see Table 3). This is consistent with the recent literature from Ramli et al. $(2016,2019)$ that find a positive relationship between firm leverage and firm performance. This assumes that the debt could give information to the investor about a firm's quality, management and efficiency strategy Harris and Raviv (1991). This is similarly with the TOT that there will be a positive relationship between firm leverage and firm financial performance where a firm has the incentive to use debt, because of the benefit of interest deduction thus leading to a positive relationship. The result of mediation effects has met all the conditions of mediation model and this also has been confirmed by using the bootstrap T-statistics proposed by Hair et al. (2018) and Preacher and Hayes (2008). We find that there are three relationships that categorize as competitive mediation which is the relationships between asset tangibility (AT), growth opportunities (GRW), firm size (FS) and firm financial performance. Previous studies (Hair et al., 2013; Mackinnon, 2000; Zhao et al., 2010) argue that the VAF value will become larger than one or, even become negative for competitive mediation. However, only one attribute which is a non-debt tax shield (NDTS) to firm financial performance categorize as a complementary mediation. Based on Zhao et al. (2010) and Rucker et al. (2011), a complementary mediation is when the indirect effect (path: a x b) and direct effect (path c) both significant and the signs pointing in the same direction. Competitive mediation is when the indirect effect (path: a $\mathrm{x}$ b) and direct effect (path c) both significant and the sign pointing in the opposite direction.

\section{Conclusion}

This study contributes to the extension of capital structure literature by examining the mediation effects of firm leverage. We used Partial Least Squares, which is a variance based Structural Equation Modelling (PLS-SEM) technique to empirically test mediating effects of leverage between the relationship of firm-specific attributes and firm financial performance in Malaysian Shariah compliant companies for the period 2000 to 2018. Usually, the previous study investigates at the concept of direct effect relationships $\mathrm{X} \rightarrow \mathrm{Y}$ (i.e., capital structure determinants) and this is a clear concept that has been understood among all researchers. However, it is often unclear how 
firm-specific attributes $(\mathrm{X})$ affect performance (Y) directly and how the concept of direct effect $\mathrm{X} \rightarrow \mathrm{Y}$ can be labelled the "effect to be mediated". Our study specifically allows for this "mediation" to define the causal relationship between $\mathrm{X}$ and $\mathrm{Y}$. This identification of the mediation effect is essential for the development of theories in corporate finance in thee ways. First, there are an exist of mediation effect of leverage for the Malaysian Shariah companies. Secondly, the direct path is rarely expected and clarified. The assertion of unexplained "direct" paths is often evidence of the effects of one or more omitted mediators. It is common for theoretical independent variables to affect the dependent variables through two (or more) mediators (Zhao et al., 2010). In that case, the unexpected sign in this study of the direct effect that emerged in "competitive mediation" (i.e., AT, GRW, FS) can provide guidelines for theory building. Thirdly, there is a complementary mediation for non-debt tax shield for Malaysian Shariah Company's sample. In debt financing, a substitute for tax benefit is the non-debt tax shield, which is an alternative method of reducing the tax burden and lead to firm employ more debt, and consequently, this will lead to high performance. The unexplained sign of the direct effect can provide a clue in future work for a second mediation mechanism. Rucker et al. (2011) and Zhao et al. (2010) suggest that the total effect might possibly be reflected by two or more omitted mediators with different signs. This may provide guidance to investors, issuers, government, corporate practitioners and academician to make appropriate capital structure decisions that can enhance firm performance. The study has important implications for managerial decisions, that is, the financial management knows the "way" and "how" its firm value would increase (decrease) from the firm characteristics and its appropriate capital structure decision from the mediation model.

\section{Acknowledgements}

We would like to give thanks to the editors and the anonymous referees of the journal for constructive comments and suggestions, which have significantly helped to improve the contents of the paper. Furthermore, special thanks to the Yayasan Tun Ismail Chair, PNB for funding the research under research grant code (USIM/YTI/FEM/052002/41018).

\section{References}

Abor, J. (2005). The effect of capital structure on profitability: An empirical analysis of listed firms in. Journal of Risk Finance, 6(5), 438-445.

Ahmad, N., \& Azhar, N. N. (2015). Investigating of Shariah compliant companies capital structure determinants. Advanced Science Letters, 21(6), 1986-1989

Ahmed, A. (2010). Global financial crisis: An Islamic finance perspective. International Journal of Islamic and Middle Eastern Finance and Management, 3(4), 306-320.

Ahmed, H. (2007). Issues in Islamic corporate finance: Capital structure in firms. Jeddah, Saudi Arabia: Islamic Research and Training Institutes (IRTI)

Al-Najjar, B., \& Hussainey, K. (2011). Revisiting the capital-structure puzzle: UK evidence. The Journal of Risk Finance, 12(4), 329-338.

Bacha, O. I., \& Mirakhor, A. (2013). Islamic capital markets: A comparative approach. John Wiley and Sons Singapore Pte. Ltd

Baharuddin, N. S., Khamis, Z., Mahmood, W. M. W., \& Dollah, H. (2011). Determinants of capital structure for listed construction companies in Malaysia. Journal of Applied Finance \& Banking, 1(2), 115-132.

Barclay, M., Smith, C. W., \& Morellec, E. (2006). On the debt capacity of growth options. Journal of Business, 79(1), 37-59.

Baron, R. M., \& Kenny, D. A. (1986). The moderator-mediator variable distinction in social psychological research: Conceptual, strategic, and statistical considerations. Journal of Personality and Social Psychology, 51(6), 1173.

Berger, A. N., \& Bonaccorsi di Patti, E. (2006). Capital structure and firm performance: A new approach to testing agency theory and an application to the banking industry. Journal of Banking \& Finance, 30(4), 1065-1102.

Booth, L., Aivazian, V., Demirguc Kunt, A., \& Maksimovic, V. (2001). Capital structures in developing countries. The Journal of Finance, 56(1), 87-130.

Byoun, S. (2011). Financial flexibility and capital structure decision. https://doi.org/10.2139/ssrn.1108850

Chakraborty, I. (2010). Capital structure in an emerging stock market: The case of India. Research in International Business and Finance, 24(3), 295-314. 
Chang, C., Lee, A. C., \& Lee, C. F. (2009). Determinants of capital structure choice: A structural equation modeling approach. The Quarterly Review of Economics and Finance, 49(2), 197-213.

Chin, W. W. (1998). The partial least squares approach for structural equation modeling. G. A. Macoulides (Ed.), Lawrence Erlbaum Associates: Mahwah, NJ.

Chin, W. W., Vinzi, V. E., Henseler, J., \& Wang, H. (2010). Handbook of partial least squares: Concepts, methods and applications. Springer.

Davis, E. P. (1995). Debt, financial fragility and systemic risk. Oxford: Oxford University Press Inc.

Deangelo, H., \& Masulis, R. W. (1980). Optimal capital structure under corporate and personal taxation. Journal of Financial Economics, 8(1), 3-29.

Deesomsak, R., Paudyal, K., \& Pescetto, G. (2004). The determinants of capital structure: Evidence from the Asia Pacific region. Journal of Multinational Financial Management, 14(4-5), 387-405.

Dessí, R., \& Robertson, D. (2003). Debt, incentives and performance: Evidence from UK panel data. The Economic Journal, 113(490), 903-919.

Donaldson, C. (1961). Corporate debt capacity: A study of corporate debt policy and the determination of corporate debt capacity. Harvard University.

Fama, E. F. (1980). Agency problem and the theory of firm. The Journal of Political Economy, 88(2), 288-307.

Fama, E. F., \& Miller, M. H. (1972). The theory of finance. Dryden Press.

Fan, J. P. H., Titman, S., \& Twite, G. (2010). An international comparison of capital structure and debt maturity choices: National Bureau of Economic Research.

Fauzias, M. N., Shaharuddin, A., Marzuki, A., \& Ramli, N. A. (2019). Revised Malaysian Shariah Screenning: Its Impact on Islamic Capital Market. Research in World Economy, 10(1), 17-30.

Frank, M. Z., \& Goyal, V. K. (2008). Trade-off and pecking order theories of debt. In B. E. Eckbo (Ed.), Handbook of corporate finance: Empirical corporate finance (Vol. 2, pp. 136-202). Amsterdam, The Netherlands: Elsevier.

González, V. M., \& González, F. (2012). Firm size and capital structure: Evidence using dynamic panel data. Applied Economics, 44(36), 4745-4754.

Grossman, S. J., \& Hart, O. D. (1982). Corporate financial structure and managerial incentives. University of Chicago Press.

Hair Jr, J. F., Hult, G. T. M., Ringle, C., \& Sarstedt, M. (2013). A primer on partial least squares structural equation modeling (PLS-SEM). SAGE Publications, Incorporated.

Hair, J. F., Sarstedt, M., Ringle, C., \& Gudergan, S. P. (2018). Advanced issues in partial least squares structural equation modeling. Thousand Oaks: Sage Publications.

Hall, T. W. (2012). The collateral channel : Evidence on leverage and asset tangibility. Journal of Corporate Finance, 18(3), 570-583.

Harris, M., \& Raviv, A. (1991). The theory of capital structure. The Journal of Finance, 46, 297-355.

Hassan, N. N. N. M., Shafi, R. M., \& Mohamed, S. (2012). The determinants of capital structure: Evaluation between Shariah-compliant and conventional companies. In 2012 International Conference on Innovation Management and Technology Research (pp. 205-209). Ieee.

Henseler, J., Ringle, C. M., \& Sinkovics, R. R. (2009). The use of partial least squares path modeling in international marketing. Advances in International Marketing, 20(1), 277-319.

Iqbal, Z., \& Mirakhor, A. (2011). An introduction to Islamic finance: Theory and Practice (2nd Editio). John Wiley \& Sons (Asia) Pte. Ltd..

Jensen, M. C., \& Meckling, W. H. (1976). Theory of the firm: Managerial behavior, agency costs and ownership structure. Journal of Financial Economics, 3(4), 305-360.

Jensen, M. C. (1986). Agency costs of free cash flow, corporate finance, and takeovers. American Economic Review, 76(2), 323-339.

Kayo, E. K., \& Kimura, H. (2011). Hierarchical determinants of capital structure. Journal of Banking \& Finance, 
$35(2), 358-371$

Khan, M. M. (1997). The Book of Wasaya. In The translation of the meanings of Sahih Al-Bukhari (p. 506). Darussalam Publishers and Distributers.

Leary, M. T., \& Roberts, M. R. (2010). The pecking order, debt capacity and information asymmetry. Journal of Financial Economics, 95(3), 332-355.

Lokken, L. (1986). Time value of money rules. Tax Law Review, 42(1), 10-80.

MacKinnon, D. P. (2000). Contrasts in multiple mediator models. In J. S. Rose, \& L. Chassin (Eds.), Multivariate applications in substance use research: New methods for new questions. Mahwah, NJ: Erlbaum.

Margaritis, D., \& Psillaki, M. (2007). Capital structure and firm efficiency. Journal of Business Finance \& Accounting, 34(9-10), 1447-1469.

Margaritis, D., \& Psillaki, M. (2010). Capital structure, equity ownership and firm performance. Journal of Banking \& Finance, 34(3), 621-632.

McConnell, J. J., \& Servaes, H. (1995). Equity ownership and the two faces of debt. Journal of Financial Economics, 39(1), 131-157.

Modigliani, F., \& Miller, M. H. (1958). The cost of capital, corporation finance and the theory Of investment. The American Economic Review, 48(3), 261-297.

Modigliani, F., \& Miller, M. H. (1963). Corporate income taxes and the cost of capital : A correction. The American Economic Review, 53(3), 433-443.

Mustapha, M., Ismail, H. B., \& Minai. (2011). Determinants of debt structure: empirical evidence from Malaysia. Paper presented at the 2nd International conference on business and economic research (2nd ICBER) proceeding.

Myers, S. C., \& Majluf, N. S. (1984). Corporate financing and investment decisions when firms have information that investors do not have. Journal of Financial Economics, 13, 187-221.

Myers, S. C. (1977). Determinants of corporate borrowing. Journal of Financial Economics, 5, 147-175.

Obaidullah, M. (2005). Islamic Financial Services. King Abdulaziz University Press.

Obaidullah, M. (2006). Teaching corporate finance from an Islamic perspective. Islamic Economics Research Centre, King Abdulaziz University Jeddah, Kingdom of Saudi Arabia.

Preacher, K. J., \& Hayes, A. F. (2004). SPSS and SAS procedures for estimating indirect effects in simple mediation models. Behavior Research Methods, Instruments, \& Computers, 36(4), 717-731

Psillaki, M., \& Daskalakis, N. (2008). Are the determinants of capital structure country or firm specific? Small Business Economics, 33(3), 319-333.

Rajan, R. G., \& Zingales, L. (1995). What do we know about capital structure? Some evidence from international data. The Journal of Finance, 50, 1421-1460.

Ramadhan, A. H., Chen, J. J., Al-Khadash, H. A., \& Atmeh, M. (2012). A mediating role of debt level on the relationship between determinants of capital structure and firm's financial performance. International Research Journal of Applied Finance, 111(1), 65-92.

Ramli, N. A., \& Nartea, G. V. (2016). Mediation effects of firm leverage in Malaysia:Partial least squares - structural equation modeling. International Journal of Economics and Financial Issues, 6(1), 301-307.

Ramli, N. A., Latan, H., \& Nartea, G. V. (2018). Why should PLS-SEM be used ratherthan regression? Evidence from the capital structure perspective. In N. Avkiran, \& C. Ringle (Eds.), Partial least squares structural equation modeling (pp.171-209). Cham: Springer International.

Ramli, N. A., Latan, H., \& Solovida, T.G., (2019). Determinants of capital structure and firm financial performance-APLS-SEM approach: Evidence from Malaysia and Indonesia. The Quarterly Review of Economics and Finance. 71, 148-160.

Ramli, N. E., \& Haron, R. (2017). Debt Determinants of Shari'ah Approved Firms: Empirical Evidence from Malaysia. Journal of Islamic Finance, 176(5872), 1-17.

Ramli, N. E., \& Haron, R. (2017). Target Capital Structure and Speed of Adjustment: A Dynamic Evidence from 
Shariah Approved Firms in Malaysia. The Journal of Muamalat and Islamic Finance Research, 204(5775), $1-27$.

Rampini, A. A., \& Viswanathan, S. (2013). Collateral and capital structure. Journal of Financial Economics, 109(1), 466-492.

Rucker, D. D., Preacher, K. J., Tormala, Z. L., \& Petty, R. E. (2011). Mediation analysis in social psychology: Current practices and new recommendations. Social and Personality Psychology Compass, 5(6), 359-371.

Suharto, U. (2014). Analysis of the concept of Islamic choice (ikhtiyór) on opportunity cost and time value of money in Islamic economics and finance. International Journal of Economics, Management and Accounting, 22(2), $1-20$.

Titman, S., \& Wessels, R. (1988). The determinants of capital structure choice. The Journal of Finance, 43(1), 1-19.

Ting, I. W. K., \& Lean, H. H. (2011). Capital structure of government-linked companies in Malaysia. Asian Academy of Management Journal of Accounting and Finance, 7(2), 137-15

Tongkong, S. (2012). Key factors influencing capital structure decision and its speed of adjustment of Thai listed real estate companies. Procedia - Social and Behavioral Sciences, 40(1), 716-720.

Uddin, N. (2015). Determinants of corporate capital structure: A theoretical integration and some empirical evidences. International Journal of Economics and Finance, 7(7), 254-277.

Vasiliou, D., Eriotis, N., \& Daskalakis, N. (2009). Testing the pecking order theory: The importance of methodology. Qualitative Research in Financial Markets, 1(2), 85-96.

Welch, I. (2004). Capital structure and stock returns. Journal of Political Economy, 112(1), 106-132.

Yu, B. (2012). Agency costs of stakeholders and capital structure: International evidence. Managerial Finance, 38(3), 303-324.

Zhao, X., Lynch, J. G., \& Chen, Q. (2010). Reconsidering Baron and Kenny: Myths and truths about mediation analysis. Journal of Consumer Research, 37(2), 197-206.

\section{Notes}

Note 1. Ramadhan et al. (2012) summarize that leverage acts as a partial mediation between the relationships of capital structure determinants and firm financial performance in the UK market by using the reference of Baron and Kenny (1986) approach.

Note 2. $\mathrm{R}^{2}$ values of $0.67,0.33$, or 0.19 in the inner path model for the endogenous variable are defined as substantial, moderate or weak, respectively (Chin, 1998, p. 323). 